\title{
POWER TO APPOINT COUNSEL IN IILINOIS HABEAS CORPUS PROCEEDINGS
}

Public attention has recently been focused on the failure of Illinois to afford adequate post-conviction hearings for prisoners allegedly detained in violation of their constitutional rights. ${ }^{x}$ Of the many factors which have contributed to this undesirable situation, ${ }^{2}$ one of the most obvious is the almost total lack of legal aid available to the prisoners. As a result, not only do many of the petitioners for post-conviction hearings seek relief under improper remedies, but the petitions are often ineffective, since the very facts vital for a substantively valid allegation are commonly omitted because of legal ignorance. Further, the disadvantage a petitioner is under if he is granted a hearing is immediately apparent. The absence of counsel in post-conviction hearings stems, in the first instance, from the financial inability of the vast majority of prisoners to employ legal services. However, the Illinois courts have not attempted to remedy this inadequacy. In 1945, the Illinois Supreme Court crystallized its usual practice of considering prisoners ${ }^{3}$ habeas corpus petitions without appointing counsel ${ }^{3}$ in its decision in People ex rel. Ross v. Ragen ${ }^{4}$ which specifically precludes Illinois judges from furnishing counsel in such proceedings.

In the Ross case, the relator, a prisoner in the state penitentiary, filed an original petition for a writ of habeas corpus before the Illinois Supreme Court. After issue and return of the writ, the relator requested, on motion, either the appointment of counsel to represent him, or that he be brought before the court at the time of hearing. The motion was denied on the ground that, since habeas corpus is a civil proceeding, the Tlinois guarantees entitling an accused to counsel in criminal cases ${ }^{5}$ were inapplicable, and that the court was therefore "neither authorized nor empowered"6 to provide counsel for the relator.

It has been uniformly held in the United States that habeas corpus, although intimately connected with the original criminal prosecution, is a civil proceed-

I Marino v. Ragen, 68 S. Ct. 240 (1947); Katz, An Open Letter to the Attorney General of Tllinois, 15 Univ. Chi. I. Rev. 25I (r947); A Study of the Illinois Supreme Court, 15 Univ. Chi. L. Rev. 107, II8 (1947).

2 "[The] virtually complete inability of prisoners to obtain hearings on their claims of denial of due process of law in their convictions calls for drastic revision of the machinery which Illinois affords for post-conviction hearings." A Study of the Illinois Supreme Court, I5 Univ. Chi. L. Rev. 107, II9 (1947).

3 Ibid., at 120.

${ }_{4} 39$ I Ill. 419, 63 N.E. 2 d 874 (I945), noted in 24 Chi-Kent Rev. 357 (I946).

5 Ill. Const. Art. 2, $\$ 9$; Ill. Rev. Stat. (I947) c. $38, \S 730$.

6 "This being a case involving only the enforcement of relator's civil right of personal liberty, separate and distinct from the criminal proceeding in which punishment for a crime was imposed upon him, he is not in the position of an 'accused' in a criminal prosecution. The court is neither authorized nor empowered to appoint counsel to appear for him." People ex rel. Ross v. Ragen, 39r Ill. 4I9, 423, 63 N.E. 2d 874, 875 (I945). 
ing. ${ }^{7}$ However, the Ross case is unique in its assertion that the non-criminal nature of the action prohibits judicial appointment of counsel. ${ }^{8}$ Even more striking is the fact that the Illinois court patently ignored the Illinois forma pauperis statute, 9 which has been in existence since 1874 . This legislation, specifically applicable to civil actions, authorizes any court, in its discretion, to permit the prosecution or defense of a suit by a poor person ${ }^{\text {I0 }}$ without fees or charges. It further provides that the court may assign counsel for such person. The court's failure in the instant case to apply the latter provision to habeas corpus proceedings is difficult to rationalize. It has not been questioned by the Illinois courts that prisoners and other indigents may petition in habeas corpus without payment of fees or costs under the forma pauperis legislation. Since the courts have thus accepted a portion of the statute as applicable to habeas corpus proceedings, it seems inconceivable that the subsequent language of the same act, authorizing appointment of counsel, can be ignored. Further, the existence at common law $\mathrm{W}^{\mathrm{II}}$ of powers identical with the statutory provisions emphasizes the error of the Ross decision.

7 The proceeding is generally considered a new suit by the one held in custody, to enforce his civil right to liberty. Fisher v. Baker, 203 U.S. I74, I8I (1906); Cross v. Burke, 146 U.S. 82, 88 (I892); Farnsworth v. Montana, I29 U.S. 104, II3 (I889); Ex parte Tom Tong, Io8 U.S. 556, 559 (1883); Brown v. Johnston, 9r F. $2 \mathrm{~d} 370,372$ (C.C.A. 9th, I942), cert. den. 302 U.S. 728 (1937). But see In re Fred Storgoff, [1945] S.C.R. 526, a recent Canadian decision holding that habeas corpus is not a civil remedy when used to question a criminal conviction.

${ }^{8}$ In Whitaker v. Johnston, 85 F. 2 d 199 (C.C.A. 9th, I936), the court stated it was "without power" to appoint an attorney for a habeas corpus petitioner. However, not only is the statement made without mention of reason or authority, but it is doubtful whether the court intended its dictum to carry the same meaning as the Ross holding, since it denied habeas corpus solely on the ground that the petition was filed in the wrong court.

9 "If any court shall, before or after the commencement of any suit, be satisfied that the plaintiff or defendant is a poor person, and unable to prosecute or defend suit and pay the costs and expenses thereof, the court may in its discretion, permit him to commence and prosecute his action, or defend suit, as a poor person; and thereupon such person shall have all the necessary writs, process, appearances and proceedings, as in other cases, without fees or charges. The court may assign to such person counsel, who, as well as all other officers of the court, shall perform their duties in such suit without any fees, charge or reward." IIl. Rev. Stat. (I947) c. $33, \$ 5$.

so All resident plaintiffs who are unable to prosecute their suits and pay costs and expenses are included in the terms of the statute. Chicago \& I.R. Co. v. Lane, I30 Ill. xI6, 22 N.E. $5 I_{3}$ (1889). Unquestionably almost every prisoner petitioning for a post-conviction hearing would fit into this category.

Ix The original forma pauperis statute, the title of which was "A Mean to Help and Speed Persons in Their Suit," was enacted in I495. II Hen. VII, c. I2 (often cited as having been passed in r494). There is reason to believe that this statute was nothing more than confirmatory of the common law. See Martin v. Superior Court, I76 Cal. 289, 168 Pac. r35 (1917); opinions of Tindal, Ch. J., and Maule, J., in Brunt v. Wardle, 3 Mann. \& G. 534, 133 Eng. Rep. 1254 (184I); cf. Annotation, Right to Sue in Forma Pauperis at Common Law or in the Absence of a Statute, L.R.A. I9I8B 3 I9 (IgI8). In any event, however, the statute would be part of Illinois common law by virtue of $\mathrm{Ml}$. Rev. Stat. (I947) c. 28, $\S \mathrm{x}$. That section provides that the "common law of England, so far as the same is applicable and of a general nature, and all statutes or acts of the British parliament made in aid of, and to supply the defects of the common law prior to the fourth year of James the First, ... . and which are of a general 
Although the issue presented by the Ross case has apparently not been decided in other states under their forma pauperis statutes ${ }^{\mathrm{T2}}$ or common law powers, ${ }^{x 3}$ it has had an extensive history in the federal courts. The federal forma pauperis statute, ${ }^{I_{4}}$ substantially the same as the Illinois act, has in the past been the basis for appointment of counsel in habeas corpus proceedings. ${ }^{x_{5}}$ While the failure of a lower federal court to provide legal representation for an indigent petitioner has not been held error where the petition was unmeritorious, ${ }^{16}$ the judicial power, under this statute, to appoint counsel in habeas corpus cases has never been doubted. In Ex parte Rosier, ${ }^{17}$ the Court of Appeals for the District of Columbia expressly pointed out the trial court's duty under the statute to consider the appointment of counsel for a "poor" habeas corpus petitioner whose cause was deemed worthy of trial. In remanding the case, the Court of Appeals said, "We shall assume in further proceedings to be had consistently with this opinion the trial court will properly exercise its discretion in respect of the appointment of counsel. . . . [It] seems obvious ... that there will be a contest on questions of fact. ... Under these circumstances, the appointment of counsel ought to be made.", ${ }_{\mathbf{I}}$

nature and not local to the kingdom, shall be the rule of decision, and shall be considered as of full force until repealed by legislative authority." The original forma pauperis statute obviously qualifies under this section.

32 Forma pauperis statutes similar to the Illinois act are to be found in a number of states. Ky. Rev. Stat. (1946) \& 453. I90; Ind. Stat. Ann. (Burns, I933) § 2-211; N.Y. Civ. Prac. Act (Cahill, r946) \$ 196-198; Mo. Rev. Stat. (1939) § r404. See also the following state legislation in which costs and fees for poor persons are provided for, but in which there is no specific provision for appointment of counsel. Miss. Code. Ann. (I942) \& I574; Wis. Stat. (Brossard, 1943) \& 271.29; Tex. Ann. Rev. Civ. Stat. (Vernon, I925) art. 2070; Okla. Stat. (r94r) tit. I2, $\$ \$ 92 I-922$.

${ }_{33}$ The original forma pauperis statute would, in the absence of contrary legislative intent, be a part of the common law of most American jurisdictions, since general statutes enacted in England prior to the fourth year of James I (in some states), or prior to the American Revolution (in others) constitute a part of the common law of the majority of states. I $_{5}$ C.J.S. $\$ \$ 4$, $\mathrm{r}_{3}$ (1939). But see the following cases to the effect that no right to sue in forma pauperis exists at common law: Harris v. Stanton, 146 Ind. 366,45 N.E. 582 (1896); Hoey v. McCarthy, 124 Ind. 464,24 N.E. I038 (189o); Roy v. Louisville N.O. \& T.R. Co., 34 Fed. 276 (C.C. Tenn., 1888); Campbell v. Chicago \& N.W.R. Co., 23 Wis. 490 (I868).

${ }^{4}{ }_{27}$ Stat. 252 ( 1892 ), as amended, 28 U.S.C.A. $\$ \$ 832-36$ ( $x_{928}$ ). See especially 28 U.S.C.A. $\$ 835$ which provides, "The court may request any attorney of the court to represent such poor person, if it deems the cause worthy of trial, and may dismiss any such cause so brought if it be made to appear that the allegation of poverty is untrue, or if said court be satisfied that the alleged cause of action is frivolous or malicious."

rs Millslagle v. Olson, I28 F. 2d ror 5 (C.C.A. 8th, I942); Ex parte Rosier, I33 F. 2 d 3 I6 (App.D.C., I942); see Dorsey v. Gill, x48 F. 2d 857 (App.D.C., r945), cert. den. 325 U.S. 890 (I945) to the effect that the court may in its discretion grant the application for the appointment of counsel for the habeas corpus petitioner.

${ }^{56}$ Gargano v. United States, 140 F. $2 d$ Ir8 (C.C.A. gth, 1944); Application of Taylor, I39

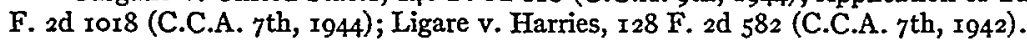

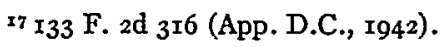

${ }^{18}$ Ibid., at 333 . 
A number of federal cases, although not referring specifically to the forma pauperis statute, have assumed the power of the courts to appoint counsel in habeas corpus actions. ${ }^{19}$ Federal courts which have denied legal representation to petitioners, or have refused to reverse a lower court's decision despite such denial, have relied solely on the ground that habeas corpus is a civil proceeding, so that the petitioner is not entitled to the Sixth Amendment's guarantee of counsel. ${ }^{20}$ These cases, however, do not indicate that counsel could not have been appointed had the courts so desired. On the contrary, in Hodges v. Huff, ${ }^{2 x}$ where the habeas corpus petitioner's request for counsel was denied in the lower court, it was held on appeal that the ". . . better practice would have been for the judge to appoint an attorney and direct him to investigate the allegations of the petition. ... But we cannot say, upon the present record, that the judge erred in failing to follow the practice indicated."22

The federal courts' recognition of the power to appoint counsel for indigent petitioners in habeas corpus actions is best illustrated by the practice of the United States Supreme Court. That Court, when granting leave to a habeas corpus petitioner to proceed in forma pauperis, has appointed counsel as a matter of course. ${ }^{23}$ The sharp contrast of this procedure with the language of the Illinois Supreme Court in the Ross case is notable in view of the nearly identical statutes involved.

Justification of the instant decision by the Illinois court could be attempted only on the basis that habeas corpus is such a peculiar type of civil proceeding that it falls outside the Illinois statute, and that appointment of counsel is thus prohibited. Such an analysis, however, could only indicate a desire to escape from literal acceptance of Illinois law, unexplainable in the light of strong public policy arguments for the opposite result.

The basic rationale supporting appointment of counsel for "poor persons" seeking relief through habeas corpus is twofold. Not only is the petitioner

${ }^{29}$ Jones v. Huff, I 52 F. $2 d$ I4 (App. D.C., r945); Gall v. Brady, 39 F. Supp. 504 (Md., I94I); see also Carey v. Brady, 39 F. Supp. 5 I 5 (Md., I94I), aff'd r25 F. 2d 253 (C.C.A. 4 th, r942), cert. den. 316 U.S. 702 (1942), wherein counsel was denied the habeas corpus petitioner, but only because counsel had been appointed in a case previously before the court which raised the identical issue.

${ }^{20}$ Petition of Wilson, 68 F. Supp. I68 (Mich., I946); Ex parte McBride, 68 F. Supp. 139 (Mich., I946); Hodge v. Huff, I40 F. 2 d 686 (App. D.C., I944), cert. den. 322 U.S. 733 (I944); Brown v. Johnston, gr F. $2 d 370$ (C.C.A. 9 th, r937).

${ }^{21}$ r40 F. $2 d 686$ (App. D.C., I944), cert. den. 322 U.S. 733 (I944).

22 Ibid., at 687 .

${ }^{23}$ See, for example, Woods v. Nierstheimer, 328 U.S. 2 Ir (x946); Rice v. Olson, 324 U.S. 786 (I945); White v. Ragen, 324 U.S. 760 (I945); Holiday v. Johnston, 313 U.S. 342 (I94I); Walker v. Johnston, 3 I 2 U.S. 275 (I94I). In the latter case, Justice Roberts said, "This case represents important questions of practice touching the issue of the writ of habeas corpus. We accordingly granted certiorari in forma pauperis, and appointed counsel for the petitioner to insure adequate presentation at our bar." Ibid., at 278 . 
more adequately represented, but the court itself is in no small measure aided by the research and presentation of argument by non-judicial court officers. The great number of legally ignorant prisoners petitioning in habeas corpus in Tllinois at present, plus the physical inability of the courts adequately to consider each of the many petitions they receive, serve only to reenforce the general reasons outlined above.

At least one Illinois court has realized the limitations inherent in a strict adherence to the language of the Ross case, and has appointed counsel as a "friend of the court" ${ }^{\prime 24}$ to advise the bench and appear on behalf of a number of prisoners who have filed petitions for writs of habeas corpus. ${ }^{25}$ It seems absurd that judges must seek such ingenious means to achieve a practical result when straightforward methods are readily available. Recognition of the applicability of the Illinois forma pauperis statute to habeas corpus proceedings would be at least a stop-gap solution to the unhappy situation that exists in Illinois today.

However, a real remedy going to the roots of the problem is perhaps possible only through legislation. A system under which "friends of the court" or uncompensated appointed counsel must be depended upon to represent vast numbers of petitioners has several disadvantages, among them the lack of time available to most attorneys in private practice, and their possible lack of interest in the absence of remuneration. ${ }^{26}$ In addition, the appointment of counsel at the stage where the court is about to hear the case, while assuredly better than no representation at all, overlooks the difficulties faced by petitioners in framing their requests for the writ to issue.

The present Illinois public defender statute, ${ }^{27}$ while susceptible of construction so as to allow legal aid to prisoners seeking post-conviction hearings, ${ }^{28}$ is not a satisfactory solution to the problem since it does not fulfil the need for unambiguous legislation dealing squarely with the dilemma of illegally detained

24 There would seem to be no objection, even under the Ross case, to the appointment of a "friend of the court." See People v. Reck, 392 Ill. 3 II, 64 N.E. 2 d 526 (1945) as to the power of Illinois courts to appoint a "friend of the court."

${ }^{25}$ Private communication of January 27, I948 from Chief Justice Harrington of the Criminal Court of Cook County to Wilber G. Katz, appointing the latter "friend of the court" to appear in behalf of a number of prisoners petitioning for habeas corpus. As a practical matter, in Cook County the Criminal Court is unofficially aided in its disposition of habeas corpus petitions by the public defender.

${ }^{26}$ Actually, attorney's compensation is not necessary either under the Illinois forma pauperis statute, note 9 supra, or at common law. Johnson v. Whiteside County, 1 Io Ill. 22, 25 (1884). Complete dependence on the interest of an unpaid counsel, however, is undesirable.

${ }_{27}$ IIl. Rev. Stat. (1945) c. 34 , $\$ \$ 163 c-j$.

${ }^{28}$ The public defender is to act as counsel "for all persons who are held in custody" as well as those who are charged with the commission of any crime. "He shall also in the case of conviction of any such person, prosecute any writ of error or other proceeding in review which in his judgment the interests of justice merit." IIl. Rev. Stat. (1947) c. $34, \S 163$ f. However no Illinois case has as yet held this section to apply to habeas corpus proceedings. 
prisoners. Further, the existing status of the public defender as a county officer ${ }^{29}$ is, for the present purpose, undesirable, as the problem is essentially one requiring state administration.

The matter could be more adequately handled, as it has been in Indiana, ${ }^{30}$ through the office of a state public defender expressly charged with the duty of representing indigent prisoners who claim unconstitutional detention. A bill basically similar to the Indiana act was introduced in the Illinois House of Representatives in r945. Under the proposed legislation, two experienced criminal lawyers, appointed by the state Supreme Court, were to be permanently employed as legal counsel for prisoners in the state penitentiary. ${ }^{3 \mathrm{~T}}$ The bill also proposed that $\$ 40,000$ be made available to the Supreme Court for "administrative expenses." Although actively supported, the bill unfortunately never became law.

Actually any arrangement would be acceptable by which prisoners seeking relief from unconstitutional detention would be assured competent representation, and by which the courts could give adequate consideration to the merits of each petition. Either of the above methods would be desirable only if they were conscientiously carried out by those charged with the duty. Intelligent legislation dealing with the matter must insure such capable administration. It is a primary duty of the next Illinois General Assembly to take appropriate action.

\section{SEARCHES AND SEIZURES: 1948}

The backwash of recent cases which swept away a small but significant fraction of the protection hitherto afforded by the Fourth Amendment ${ }^{x}$ appears to have run its course. Whatever rationale may account for the decisions in Davis

29 The present public defender statute applies only to Cook County. Ill. Rev. Stat. (I947) c. $34, \S 16_{3}$ c. Even if all counties were provided for, however, the same objections would be present.

${ }^{30}$ In Indiana it is now the duty of the public defender, appointed by the state Supreme Court, to represent prisoners who are paupers "in any matter in which such person may assert he is unlawfully or illegally imprisoned, after his time for appeal shall have expired." Ind.Stat. Ann. (Burns, Supp., I945) $\S x_{3}-1402$.

${ }^{3 x}$ The proposed bill fixed the salaries of the attorneys at $\$ 7,500$ per annum. The two appointees were to be required, in addition to aiding prisoners directly, to perform such other duties as the Supreme Court judges might direct. III. H.B. 534, 64th Assemb., Reg. Sess. (Tabled June 28, I945).

I "The right of the people to be secure in their persons, houses, papers, and effects, against unreasonable searches and seizures, shall not be violated, and no Warrants shall issue, but upon probable cause, supported by oath or affirmation, and particularly describing the place to be searched, and the persons or things to be seized." 